\title{
Association of short-term exposure to sulfur dioxide and hospitalization for ischemic and hemorrhagic stroke in Guangzhou, China
}

Shuqun Shen ${ }^{1+}$, Xing $\mathrm{Li}^{2+}$, Chao Yuan ${ }^{3,4}$, Qin Huang ${ }^{5,6}$, Dongyang Liư ${ }^{7}$, Shuoyi Ma ${ }^{8}$, Jialiang Hui ${ }^{9}$, Ruiyu Liu ${ }^{9}$, Tongwei $\mathrm{Wu}^{9}$ and Qing Chen ${ }^{1 *}$ (D)

\begin{abstract}
Background: In developing countries, ambient sulfur dioxide $\left(\mathrm{SO}_{2}\right)$ is a serious air pollutant concern, but there is no enough and consistent epidemiological evidence about its health effects on stroke hospitalization.

Methods: We collected the daily air pollution data, meteorological data and number of daily hospital admissions for ischemic and hemorrhagic stroke, in Guangzhou from January 1st 2009 to December 31st 2014. Then we applied generalized additive model with a quasi-Poisson link to assess the relationship between short-term $\mathrm{SO}_{2}$ exposure and the total number of hospital admissions for ischemic and hemorrhagic stroke. In addition, we evaluated the effect of ambient $\mathrm{SO}_{2}$ by age ( $<65$ years and $\geq 65$ years).

Results: During the study period, a $24-\mathrm{h}$ mean concentration of ambient $\mathrm{SO}_{2}$ of $27.82 \mu \mathrm{g} / \mathrm{m}^{3}$, a total of 58,473 ischemic stroke and 9167 hemorrhagic stroke hospital admissions hospital were recorded. Ambient $\mathrm{SO}_{2}$ was found to increase the risk for both ischemic and hemorrhagic stroke hospital admission in single pollutant model. The maximum value of percentage changes for ischemic and hemorrhagic stroke occurred in lag 0 day and lag 1 day, per $10 \mathrm{\mu g} / \mathrm{m}^{3}$ increase in $\mathrm{SO}_{2}$ concentrations was corresponded to a $1.27 \%$ (95\% confidence interval $(\mathrm{Cl}), 0.42-$ $2.12 \%)$ and $1.55 \%(95 \% \mathrm{Cl}, 0.02-3.11 \%)$ increased risk, respectively. The association between $\mathrm{SO}_{2}$ and ischemic stroke hospitalization was robust to two pollutant model, but for hemorrhagic stroke it's partially weakened after adjusting for co-pollutants. The effect of ambient $\mathrm{SO}_{2}$ on ischemic stroke appeared to be greater for people $<65$ years old, but null effect on hemorrhagic stroke was identified for both age groups.

Conclusions: We found short-term exposure to ambient $\mathrm{SO}_{2}$ may significantly increase the risks of hospitalization for ischemic stroke. The findings may contribute to a better understanding of the health effects of low-levels of $\mathrm{SO}_{2}$.
\end{abstract}

Keywords: Sulfur dioxide, Ischemic stroke, Hemorrhagic stroke, Hospital admission, China

\footnotetext{
* Correspondence: 18002270308@163.com

'Shuqun Shen and Xing Li contributed equally to this work.

'School of Public Health, Southern Medical University, 1838\#Guangzhou

North Avenue, Guangzhou, Guangdong 510515, People's Republic of China

Full list of author information is available at the end of the article
}

(c) The Author(s). 2020 Open Access This article is distributed under the terms of the Creative Commons Attribution 4.0 International License (http://creativecommons.org/licenses/by/4.0/), which permits unrestricted use, distribution, and reproduction in any medium, provided you give appropriate credit to the original author(s) and the source, provide a link to the Creative Commons license, and indicate if changes were made. The Creative Commons Public Domain Dedication waiver (http://creativecommons.org/publicdomain/zero/1.0/) applies to the data made available in this article, unless otherwise stated. 


\section{Background}

Stroke is the second leading cause of death in the world [1]. According to Global Burden of Disease (GBD) Study 2016, the highest age-standardized incidences of stroke were observed in east Asia, especially China (354 [95\% UI 331-378] per 100,000 person-years) [2]. Ischemic stroke and hemorrhagic stroke account for approximately 70 and $28 \%$ of all stroke cases, respectively [3]. Moreover, the incidence of stroke continues to rise in China in recent years [3]. Therefore, identification of modifiable risk factors for stroke has significant public health implications.

Hypertension, diabetes mellitus and dyslipidemia are major risk factors for cardiovascular diseases including stroke $[4,5]$. The high prevalence of these risk factors is a major burden to most economies around the world. Ambient air pollution is also a well-known risk factor for stroke morbidity [6], but the majority of evidence are focused on particulate matter $(\mathrm{PM})[7,8]$. Sulfur dioxide $\left(\mathrm{SO}_{2}\right)$ is a non-flammable, colorless gas with a strong pungent odor at room temperature, which is primarily released from the combustion of sulfur containing fossil fuels at power plants (73\%) and other industry facilities (20\%) [9]. As a strong respiratory irritant and bronchoconstrictor, $\mathrm{SO}_{2}$ could induce systemic inflammation and oxidative stress [10], which might take a role in stroke. Short-term exposure to ambient $\mathrm{SO}_{2}$ was associated with increased risk of stroke morbidity in a meta-analysis mainly based on developed countries [6]. However, in developing countries like China, the evidence is limited and very few studies [11] distinguished between ischemic and hemorrhagic stroke. Most studies only focused on ischemic stroke but the results have not been conclusive yet, with some finding evidence of a positive association [12] but not in other studies [13-16].

Guangzhou is one of the most densely populated cities in China. The industrial production and traffic burden make $\mathrm{SO}_{2}$ one of the main atmospheric pollution sources in Guangzhou [16], which is severer than those in developed countries [17]. Moreover, the stroke mortality in Guangzhou was relatively higher compared to other cities of China [18].

Therefore, we conducted a time-series study to examine the short-term association between ambient $\mathrm{SO}_{2}$ and hospital admissions of ischemic and hemorrhage stroke in Guangzhou, respectively.

\section{Method}

\section{Study setting}

Guangzhou is located in the South China, which has a typical subtropical humid-monsoon climate with an average annual temperature of $22^{\circ} \mathrm{C}$ and an average rainfall of $1500-2000 \mathrm{~mm}$ [19]. There are 12.7 million people lived in Guangzhou in 2010 [20]. The city is one of the top-ranking commercial and manufacturing regions in China. As the economy develops in Guangzhou, it also introduces severe air pollution problems which might lead to risks to human health [21].

\section{Data sources}

We obtained the air quality monitoring data from the public sharing system of Guangzhou Environmental Monitoring Center (http://210.72.1.33:8023/gzaqi_new/ RealTimeDate.html), which includes data of all the 11 national air quality monitor stations in Guangzhou. The data of $\mathrm{SO}_{2}$, nitrogen dioxide $\left(\mathrm{NO}_{2}\right)$ and suspended particulates smaller than $10 \mu \mathrm{m}$ in aerodynamic diameter $\left(\mathrm{PM}_{10}\right)$ covered the period from January 1, 2009 to December 31, 2014. But for suspended particulates smaller than $2.5 \mu \mathrm{m}$ in aerodynamic diameter $\left(\mathrm{PM}_{2.5}\right)$ and ozone $\left(\mathrm{O}_{3}\right)$, the data was limited to the period of March 8, 2012 to December 31, 2014, because Guangzhou Environmental Monitoring Center started the surveillance of $\mathrm{PM}_{2.5}$ and $\mathrm{O}_{3}$ from March 8, 2012. All data from the monitoring stations were averaged in the present study. We used daily average concentration for $\mathrm{SO}_{2}, \mathrm{NO}_{2}$, $\mathrm{PM}_{10}, \mathrm{PM}_{2.5}$, and daily maximum 8 - $\mathrm{h}$ average $\left(\mathrm{O}_{3}-8 \mathrm{~h}\right.$ $\max$ ) for $\mathrm{O}_{3}$.

Daily meteorological data (daily mean temperature and relative humidity) from January 1, 2009 to December 31, 2014 were obtained from the China Meteorological Data Sharing Service System. All meteorological stations were averaged in the analysis.

The data on air pollution and meteorology follow the quality control programs mandated by the Chinese government. These types of data have been widely used to explore their effects on morbidity and mortality in Guangzhou [22-24].

Daily hospital admissions data were obtained from eight hospitals in Guangzhou during January 1, 2009 to December 31, 2014. If there were recurrent strokes occurring within 28 days of a previous admission, then it was treated as a single stroke event [25]. All the cases were coded under the World Health Organization's International Classification of Diseases, the 10th version (ICD-10). Ischemic and hemorrhagic stroke hospital admissions were identified as I63 and I61, respectively.

This study does not involve experimental animals or individual information on human subjects. Ethical approval was not required for this study. Research projects that do not involve human participants, their data or tissue do not require ethical review by the ethics committee in Southern Medical University.

\section{Statistical analysis}

To assess the relationship between short-term exposure of $\mathrm{SO}_{2}$ and stroke hospital admissions, we applied a generalized additive model (GAM) with Poisson link in this study [26]. In accordance with previous studies, we used 7 degrees of freedom (df) per year for the smooth function of 
calendar time to control for fluctuations in hospitalization on long time trend and seasonality [27], $6 \mathrm{df}$ for the current day's temperature, and $3 \mathrm{df}$ for relative humidity [28]. Day of the week (DOW) was also included as a dummy variable.

We first used the single pollutant model to examine the independent association between $\mathrm{SO}_{2}$ and ischemic/ hemorrhagic stroke risk. Then two pollutant model including another pollutant was built to test if there are any potential cofounding effects of other pollutant (e.g. $\mathrm{NO}_{2}$ ) on the relationship between $\mathrm{SO}_{2}$ and stroke.

These models can be generically represented as:

Single pollutant model:

$\log \left[E\left(Y_{t}\right)\right]=\alpha+\beta_{i} X_{i}+s($ temperature, $d f=6)+s$ (humidity, $\mathrm{df}=3)+\mathrm{DOW}+\mathrm{s}($ time, $\mathrm{df}=7 /$ year $)$.

Two pollutants model:

$\log \left[\mathrm{E}\left(\mathrm{Y}_{\mathrm{t}}\right)\right]=\alpha+\Sigma \beta_{\mathrm{i}} \mathrm{X}_{\mathrm{i}}+\mathrm{s}$ (temperature, $\left.\mathrm{df}=6\right)+\mathrm{s}$ (humidity, $\mathrm{df}=3)+\mathrm{DOW}+\mathrm{s}$ (time, $\mathrm{df}=7 /$ year $)$.

where $E\left(Y_{t}\right)$ stands for the expected number of stroke hospital admissions on day $t . \alpha$ represent the intercept. $\mathrm{X}$ is the concentrations of pollutant $\left(\mathrm{SO}_{2}, \mathrm{PM}_{10}, \mathrm{PM}_{2.5}\right.$, $\mathrm{NO}_{2}$ and $\left.\mathrm{O}_{3}\right) . \beta_{\mathrm{i}}$ stands for the coefficient for $\mathrm{X}_{\mathrm{i}} \mathrm{s}()$ represented a smoother based on penalized smoothing splines, which captures the nonlinear relationships of the covariates of time trend, temperature and humidity with daily hospitalization. df represents the degree of freedom. Daily mean temperature and relative humidity were used in all models to control for confounding. Time is the time to adjust for long-term trend and seasonality.

To explore the potential modification, we examined outcomes by stratification of age ( $\geq 65$ years and $<65$ years). We also conducted sensitivity analyses to check the robustness of results by changing the degrees of freedom in the smooth function of time trend (7-9 per year). $P$ value $<0.05$ was considered as statistically significant. All the analyses were performed with $\mathrm{R}$ software ( $\mathrm{R}$ Development Core Team, 2015).

\section{Results}

Table 1 presented the stroke, meteorological and air pollution data in Guangzhou during January 1, 2009 to December 31, 2014. Overall, 58,473 ischemic stroke and 9167 hemorrhagic stroke hospital admissions were recorded, the distribution of age is presented in Supplementary Table 1 . The daily average temperature was $21.99^{\circ} \mathrm{C}$ while daily relative humidity was $76.30 \%$. The average concentrations of air pollutants including $\mathrm{SO}_{2}$, $\mathrm{PM}_{10}, \mathrm{PM}_{2.5}, \mathrm{NO}_{2}$ and $\mathrm{O}_{3}$ were $27.82 \mu \mathrm{g} / \mathrm{m}^{3}, 72.93 \mu \mathrm{g} / \mathrm{m}^{3}$, $46.07 \mu \mathrm{g} / \mathrm{m}^{3}, 54.33 \mu \mathrm{g} / \mathrm{m}^{3}$ and $68.69 \mu \mathrm{g} / \mathrm{m}^{3}$, respectively.

The correlation coefficients between $\mathrm{SO}_{2}$ and other pollutants varied from 0.31 to 0.48 . And $\mathrm{SO}_{2}$ is negatively correlated with humidity, which is opposite to temperature. (Supplementary Table 2).

For ischemic stroke, we observed the maximum effect of $\mathrm{SO}_{2}$ at lag0 day (Table 2). Every $10 \mu \mathrm{g} / \mathrm{m}^{3}$ increase of $\mathrm{SO}_{2}$ was associated with $1.27 \%(95 \% \mathrm{CI}, 0.42-2.12 \%)$ increase of ischemic stroke (Table 2). In all the two-pollutant models, the effects of $\mathrm{SO}_{2}$ remained in line with that of single pollutant model (Table 4). When looking into the different age groups, a $10 \mu \mathrm{g} / \mathrm{m}^{3}$ increase of $\mathrm{SO}_{2}$ concentrations on lag 0 day represented $1.39 \%$ (95\%CI, 0.35 $2.45 \%$ ) and $1.21 \%$ (95\% CI, $0.02-2.42 \%)$ increment for ischemic stroke hospital admissions in $<65$ and $\geq 65$ years old group, respectively (Table 3). And we found $\mathrm{SO}_{2}$ still increased the risk of hemorrhagic stroke hospital admission with the adjustment of $\mathrm{NO}_{2}$ and $\mathrm{O}_{3}$ for $<65$ years

Table 1 Daily mortality, weather and air pollution data in Guangzhou (2009-2014)

\begin{tabular}{|c|c|c|c|c|c|c|}
\hline & Mean (SD) & Min & $P_{25}$ & $P_{50}$ & $P_{75}$ & Max \\
\hline \multicolumn{7}{|c|}{ Daily stroke hospital admissions } \\
\hline Ischemic stroke & $27(18)$ & 1 & 14 & 21 & 35 & 101 \\
\hline Hemorrhagic stroke & $4(3)$ & 0 & 2 & 4 & 6 & 15 \\
\hline \multicolumn{7}{|l|}{ Weather } \\
\hline Temperature $\left({ }^{\circ} \mathrm{C}\right)$ & $21.99(6.37)$ & 4.80 & 17.40 & 23.40 & 27.30 & 32.30 \\
\hline Humidity (\%) & $76.30(12.48)$ & 27.00 & 69.00 & 79.00 & 85.00 & 100.00 \\
\hline \multicolumn{7}{|l|}{ Air pollutant } \\
\hline $\mathrm{SO}_{2}\left(\mu \mathrm{g} / \mathrm{m}^{3}\right)$ & $27.82(18.85)$ & 2.00 & 14.42 & 22.21 & 36.00 & 116.00 \\
\hline $\mathrm{NO}_{2}\left(\mu \mathrm{g} / \mathrm{m}^{3}\right)$ & $54.33(23.90)$ & 0.00 & 37.87 & 49.32 & 65.93 & 24.100 \\
\hline $\mathrm{PM}_{10}\left(\mu \mathrm{g} / \mathrm{m}^{3}\right)$ & $72.93(42.15)$ & 3.00 & 44.00 & 64.00 & 94.41 & 417.00 \\
\hline $\mathrm{PM}_{2.5}\left(\mu \mathrm{g} / \mathrm{m}^{3}\right)^{\mathrm{a}}$ & $46.07(24.77)$ & 6.90 & 28.78 & 43.40 & 62.86 & 156.35 \\
\hline $\mathrm{O}_{3}\left(\mu \mathrm{g} / \mathrm{m}^{3}\right)^{\mathrm{a}}$ & $68.69(25.50)$ & 7.00 & 51.27 & 85.80 & 127.91 & 326.55 \\
\hline
\end{tabular}

Abbreviations: $\mathrm{SO}_{2}$ sulfur dioxide; $\mathrm{NO}_{2}$ nitrogen dioxide; $\mathrm{O}_{3}$ ozone; $P M_{10}$ particulate matter with aerodynamic diameter less than $10 \mu$ m; $P M_{2.5}$ particulate matter with aerodynamic diameter less than $2.5 \mu \mathrm{m} ; \mathrm{P}_{25}, \mathrm{P}_{50}, \mathrm{P}_{75}$, the 25th, 50th and 75th percentile

a data were in the period of March 8, 2012 to December 31, 2014 
Table 2 The percent change of stroke risk associated with $10 \mu \mathrm{g} / \mathrm{m}^{3}$ and per IQR increase of $\mathrm{SO}_{2}$ in different lag days in single pollutant model

\begin{tabular}{llll}
\hline Lag Day & & Ischemic stroke & Hemorrhagic stroke \\
\hline Lag 0 & per $10 \mu \mathrm{g} / \mathrm{m}^{3}$ & $\mathbf{1 . 2 7}(\mathbf{0 . 4 2 - 2 . 1 2 )}$ & $1.48(-0.07-3.05)$ \\
& per IQR & $\mathbf{2 . 7 5}(\mathbf{0 . 9 0 - 4 . 6 3 )}$ & $3.22(-0.15-6.69)$ \\
Lag 1 & per $10 \mu \mathrm{g} / \mathrm{m}^{3}$ & $\mathbf{0 . 9 3}(\mathbf{0 . 0 9 - 1 . 7 8 )}$ & $\mathbf{1 . 5 5}(\mathbf{0 . 0 2 - 3 . 1 1 )}$ \\
& per IQR & $\mathbf{2 . 0 2}(\mathbf{0 . 1 9 - 3 . 8 8 )}$ & $\mathbf{3 . 3 8} \mathbf{( 0 . 0 4 - 6 . 8 2 )}$ \\
Lag 2 & per $10 \mu \mathrm{g} / \mathrm{m}^{3}$ & $0.37(-0.45-1.21)$ & $\mathbf{1 . 5 2}(\mathbf{0 . 0 2 - 3 . 0 4 )}$ \\
& per IQR & $0.81(-0.98-2.62)$ & $\mathbf{3 . 3 0}(\mathbf{0 . 0 4 - 6 . 6 7 )}$ \\
Lag 3 & per $10 \mu \mathrm{gg} / \mathrm{m}^{3}$ & $0.48(-0.34-1.30)$ & $0.92(-0.55-2.41)$ \\
& per IQR & $1.04(-0.73-2.83)$ & $1.99(-1.19-5.27)$ \\
\hline
\end{tabular}

Abbreviations: IQR interquartile increase; $\mathrm{NO}_{2}$ nitrogen dioxide; $\mathrm{O}_{3}$ ozone; $P M_{10}$ particulate matter with aerodynamic diameter less than $10 \mu \mathrm{m} ; P M_{2.5}$ particulate matter with aerodynamic diameter less than $2.5 \mu \mathrm{m} ; \mathrm{SO}_{2}$ sulfur dioxide

(Table 4). But null association existed in two pollutant model for $\geq 65$ years (Table 4).

For hemorrhagic stroke, the effect of $\mathrm{SO}_{2}$ reached the maximum value on lag1 day (Table 2), with percentage change of $1.55 \%$ (95\% CI, $0.02-3.11 \%$ ) per $10 \mu \mathrm{g} / \mathrm{m}^{3}$. But neither of the effect is significant in $<65$ and $\geq 65$ years old group (Table 3). The effect of $\mathrm{SO}_{2}$ lost statistical significance after including $\mathrm{NO}_{2}, \mathrm{PM}_{10}$ and $\mathrm{PM}_{2.5}$ but it's still significant when $\mathrm{O}_{3}$ was included (Table 4).

Sensitivity analyses were performed to check the robustness of results in terms of the degrees of freedom in the smooth function of time trend, which was similar to that in the main model (Supplementary Table 3).

\section{Discussion}

This is one of the few studies specified not only association between $\mathrm{SO}_{2}$ and ischemic stroke but also hemorrhagic stroke hospital admissions in developing countries so far.

Our study suggested that ambient $\mathrm{SO}_{2}$ was significantly associated with increased hospital admissions for ischemic stroke. A $10 \mu \mathrm{g} / \mathrm{m}^{3}$ increase of the same day/lag 1 day $\mathrm{SO}_{2}$ was associated with increments of $1.27 \%$ $(0.42-2.12 \%)$ and $0.93 \%(0.09-1.78 \%)$ ischemic stroke hospital admissions risk, respectively. The associations were robust to the adjustment of all the other air pollutants. For example, the most informative pollutant of traffic emissions $\mathrm{NO}_{2}$. The association were comparable to previously studies $[6,11,12,16]$.

However, the associations of $\mathrm{SO}_{2}$ and hemorrhagic stroke were more variable and imprecise. We observed significant associations between lag 1/lag 2 days $\mathrm{SO}_{2}$ exposures and hemorrhagic stroke hospitalization risk, with percentage change of $1.55 \%(0.02-3.11 \%)$ and $1.52 \%(0.02-3.04 \%)$, respectively. But when adjusted for other air pollutants in our models (except $\mathrm{O}_{3}$ ), the magnitude of risk due to $\mathrm{SO}_{2}$ exposure turned out to be statistically insignificant. Previous evidences on $\mathrm{SO}_{2}$ hemorrhagic stroke association are scarce and inconsistent $[11,29]$. The discrepant results on hemorrhagic stroke may be explained by differences in average pollutant levels, meteorological patterns and population characteristics between studies [30]. For example, in the study of Liu et al. [11], $\mathrm{SO}_{2}$ concentration level was $39.6 \pm 41.2 \mu \mathrm{g} / \mathrm{m}^{3}$ with remarkably higher variation than that in Guangzhou $\left(21.99 \pm 6.37 \mu \mathrm{g} / \mathrm{m}^{3}\right)$ in our study. The exposure levels and exposure patterns might partly explain the difference.

The identification of potentially vulnerable subpopulation has significant implications for public health [12], therefore we stratified the stroke cases into $<65$ and $\geq 65$ years groups. For ischemic stroke, we found that the effect estimates of $\mathrm{SO}_{2}$ were higher for the $<65$ than that in the $\geq 65$ age group, which is the opposite of Tian et al. [12]. This may be due to the varied activity patterns for different age groups in different cities. The elderly in Guangzhou tend to stay in door or in the park nearby, while people under 65 years old usually take vehicles or public transportation to work and have more

Table 3 The percent change of stroke risk associated with $10 \mu \mathrm{g} / \mathrm{m}^{3}$ and per $\mathrm{IQR}$ increase of $\mathrm{SO}_{2}$ in different lag days and age group (single pollutant model)

\begin{tabular}{|c|c|c|c|c|c|}
\hline \multirow{2}{*}{$\begin{array}{l}\text { Lag } \\
\text { Day }\end{array}$} & & \multicolumn{2}{|l|}{ Ischemic stroke } & \multicolumn{2}{|l|}{ Hemorrhagic stroke } \\
\hline & & $<65$ years & $\geq 65$ years & $<65$ years & $\geq 65$ years \\
\hline \multirow[t]{2}{*}{$\operatorname{Lag} 0$} & per $10 \mu \mathrm{g} / \mathrm{m}^{3}$ & $1.39(0.35-2.45)$ & $1.21(0.02-2.42)$ & $1.55(-0.14-3.26)$ & $1.04(-2.04-4.23)$ \\
\hline & per IQR & $3.03(0.75-5.36)$ & $2.64(0.05-5.30)$ & $3.37(-0.29-7.18)$ & $2.27(-4.36-9.35)$ \\
\hline \multirow[t]{2}{*}{ Lag 1} & per $10 \mu \mathrm{g} / \mathrm{m}^{3}$ & $1.31(0.27-2.35)$ & $0.68(-0.50-1.88)$ & $1.47(-0.18-3.16)$ & $0.25(-2.79-3.40)$ \\
\hline & per IQR & $2.84(0.59-5.14)$ & $1.48(-1.08-4.10)$ & $3.21(-0.39-6.93)$ & $0.55(-5.93-7.48)$ \\
\hline \multirow[t]{2}{*}{$\operatorname{Lag} 2$} & per $10 \mu \mathrm{g} / \mathrm{m}^{3}$ & $0.80(-0.22-1.82)$ & $0.03(-1.13-1.20)$ & $0.65(-0.97-2.30)$ & $2.31(-0.69-5.40)$ \\
\hline & per IQR & $1.73(-0.47-3.98)$ & $0.06(-2.43-2.61)$ & $1.41(-2.09-5.03)$ & $5.06(-1.48-12.03)$ \\
\hline \multirow[t]{2}{*}{$\operatorname{Lag} 3$} & per $10 \mu \mathrm{g} / \mathrm{m}^{3}$ & $0.82(-0.19-1.83)$ & $0.24(-0.91-1.40)$ & $1.18(-0.42-2.81)$ & $-0.57(-3.49-2.44)$ \\
\hline & per IQR & $1.77(-0.4-3.99)$ & $0.51(-1.95-3.04)$ & $2.57(-0.90-6.16)$ & $-1.23(-7.39-5.33)$ \\
\hline
\end{tabular}

Abbreviations: IQR interquartile increase; $\mathrm{NO}_{2}$ nitrogen dioxide; $\mathrm{O}_{3}$ ozone; $P M_{10}$ particulate matter with aerodynamic diameter less than $10 \mu \mathrm{m}$; $P M_{2.5}$ particulate matter with aerodynamic diameter less than $2.5 \mu \mathrm{m} ; \mathrm{SO}_{2}$ sulfur dioxide 
Table 4 Percentage increase of stroke risk associated with per $10 \mu \mathrm{g} / \mathrm{m}^{3}$ and per $\mathrm{IQR}$ increase of $\mathrm{SO}_{2}$ under single and two-pollutant models

\begin{tabular}{|c|c|c|c|c|c|c|}
\hline \multirow{2}{*}{$\begin{array}{l}\text { Age } \\
\text { group }\end{array}$} & \multirow[t]{2}{*}{ Pollutant } & \multirow[t]{2}{*}{ Model type } & \multicolumn{2}{|l|}{ Ischemic stroke ${ }^{a}$} & \multicolumn{2}{|l|}{ Hemorrhagic stroke\# } \\
\hline & & & per $10 \mu \mathrm{g} / \mathrm{m}^{3}(95 \% \mathrm{Cl})$ & per IQR $(95 \% \mathrm{Cl})$ & per $10 \mu \mathrm{g} / \mathrm{m}^{3}(95 \% \mathrm{Cl})$ & per IQR (95\%Cl) \\
\hline \multirow[t]{6}{*}{ All age } & \multirow[t]{6}{*}{$\mathrm{SO}_{2}$} & Single pollutant & $1.27(0.42-2.12)$ & $2.75(0.90-4.63)$ & $1.55(0.02-3.11)$ & $3.38(0.04-6.82)$ \\
\hline & & Two-pollutant & & & & \\
\hline & & $\mathrm{SO}_{2}+\mathrm{NO}_{2}$ & $1.34(0.31-2.37)$ & $2.90(0.66-5.20)$ & $1.25(-0.48-3.01)$ & $2.72(-1.04-6.62)$ \\
\hline & & $\mathrm{SO}_{2}+\mathrm{PM}_{10}$ & $1.21(0.18-2.26)$ & $2.64(0.39-4.94)$ & $0.89(-0.89-2.7)$ & $1.93(-1.91-5.91)$ \\
\hline & & $\mathrm{SO}_{\mathbf{2}}+\mathrm{PM}_{2.5}$ & $2.25(0.06-4.48)$ & $4.91(0.12-9.93)$ & $2.71(-1.39-6.98)$ & $5.94(-2.98-15.68)$ \\
\hline & & $\mathrm{SO}_{2}+\mathrm{O}_{3}$ & $2.68(0.75-4.65)$ & $5.88(1.63-10.3)$ & $4.32(0.63-8.15)$ & $9.56(1.36-18.43)$ \\
\hline \multirow[t]{6}{*}{$<65$ years } & \multirow[t]{6}{*}{$\mathrm{SO}_{2}$} & Single pollutant & $1.39(0.35-2.45)$ & $3.03(0.75-5.36)$ & $1.47(-0.18-3.16)$ & $3.21(-0.39-6.93)$ \\
\hline & & Two-pollutant & & & & \\
\hline & & $\mathrm{SO}_{2}+\mathrm{NO}_{2}$ & $1.59(0.36-2.83)$ & $3.46(0.78-6.21)$ & $1.07(-0.8-2.97)$ & $2.32(-1.71-6.51)$ \\
\hline & & $\mathrm{SO}_{2}+\mathrm{PM}_{10}$ & $1.22(-0.02-2.47)$ & $2.64(-0.04-5.40)$ & $1.37(-0.55-3.33)$ & $2.98(-1.18-7.32)$ \\
\hline & & $\mathrm{SO}_{\mathbf{2}}+\mathrm{PM}_{2.5}$ & $2.23(-0.39-4.93)$ & $4.88(-0.85-10.94)$ & $3.94(-0.58-8.68)$ & $8.71(-1.25-19.67)$ \\
\hline & & $\mathrm{SO}_{2}+\mathrm{O}_{3}$ & $3.70(1.36-6.09)$ & $8.15(2.95-13.60)$ & $4.45(0.38-8.69)$ & $9.85(0.82-19.69)$ \\
\hline \multirow[t]{6}{*}{$\geq 65$ years } & \multirow[t]{6}{*}{$\mathrm{SO}_{2}$} & Single pollutant & $1.21(0.02-2.42)$ & $2.64(0.05-5.30)$ & $0.25(-2.79-3.40)$ & $0.55(-5.93-7.48)$ \\
\hline & & Two-pollutant & & & & \\
\hline & & $\mathrm{SO}_{2}+\mathrm{NO}_{2}$ & $1.09(-0.32-2.51)$ & $2.36(-0.69-5.51)$ & $0.67(-2.79-4.26)$ & $1.45(-5.93-9.42)$ \\
\hline & & $\mathrm{SO}_{2}+\mathrm{PM}_{10}$ & $1.19(-0.23-2.63)$ & $2.58(-0.5-5.75)$ & $-1.21(-4.71-2.41)$ & $-2.6(-9.89-5.28)$ \\
\hline & & $\mathbf{S O}_{\mathbf{2}}+\mathrm{PM}_{2.5}$ & $2.19(-0.49-4.94)$ & $4.78(-1.06-10.96)$ & $-0.96(-8.36-7.03)$ & $-2.06(-17.17-15.8)$ \\
\hline & & $\mathrm{SO}_{2}+\mathrm{O}_{3}$ & $1.90(-0.45-4.31)$ & $4.14(-0.98-9.52)$ & $1.62(-5.14-8.85)$ & $3.52(-10.76-20.08)$ \\
\hline
\end{tabular}

Abbreviations: IQR interquartile increase; $\mathrm{NO}_{2}$ nitrogen dioxide; $\mathrm{O}_{3}$ ozone; $P M_{10}$ particulate matter with aerodynamic diameter less than $10 \mu \mathrm{m} ; P M_{2.5}$ particulate matter with aerodynamic diameter less than $2.5 \mu \mathrm{m} ; \mathrm{SO}_{2}$ sulfur dioxide

Ischemic stroke ${ }^{a}$ : models were based on lag 0 (maximum effect day in single model). Hemorrhagic stroke\#: models were based on lag 1 (maximum effect day in single model)

exposure on $\mathrm{SO}_{2}$, because the vehicle exhaust emission is one of the main sources of $\mathrm{SO}_{2}$. But for hemorrhagic stroke hospitalization, there was no evidence of effect in neither age subgroup in any lag structure. It might be related to the smaller number of daily hospital admissions of hemorrhagic stroke $(4 \pm 3$ cases/day) in this study. The lower incidence of hemorrhagic stroke may lead to larger imprecision in the estimates [6]. In addition, we noted that $70.14 \%$ hemorrhagic stroke cases were $<65$ years old, while $59.75 \%$ ischemic stroke cases were $\geq 65$ years old, which was similar to previous observations [11]. But the different age distribution of ischemic and hemorrhagic stroke should not be ignored. It might also contribute to the different relationship between $\mathrm{SO}_{2}$ and ischemic and hemorrhagic stroke.

The mechanism behind the adverse stroke effects associated with $\mathrm{SO}_{2}$ is biological plausible. The inhalation of $\mathrm{SO}_{2}$ could alter heart rate variability, elevate oxidative and enhanced blood coagulation and thrombosis formation [31]. Animal study also showed that $\mathrm{SO}_{2}$ elevated the levels of cyclooxygenase-2, interleukin-1b, tumor necrosis factor-a, intercellular adhesion molecule-1 mRNA and protein, which might also play a role in the development of stroke [32]. These pathophysiologic changes may be related to the development and progression of stroke. Nevertheless, the exact biological pathways underlying the health impact of $\mathrm{SO}_{2}$ need further investigations.

Although this study found that the magnitude of elevated risk of stroke due to $\mathrm{SO}_{2}$ exposures in Guangzhou was relatively small, it should not be ignored. Coal related air pollution, characterized by high level of $\mathrm{SO}_{2}$, remains to be an important environmental problem in China, including Guangzhou [10]. The increased risk of ischemic stroke and hemorrhagic stroke due to the exposures of $\mathrm{SO}_{2}$ estimated in this work highlights the need for continued vehicle emission control, desulfurization, and promotion of hydropower and nuclear power from the government [33] and vigilance for the health risks of air pollution. There are several limitations of this study. First, averaging air pollution exposures over Guangzhou may introduce exposure measurement error. Secondly, as a retrospective ecological study, personal exposure confounders could not be excluded in the model, and we have no access to individual air pollution exposure data. Further studies based on personal measurements or modeled residential concentrations are warranted to evaluate the health effects of $\mathrm{SO}_{2}$, especially at low levels or in the real world. Moreover, the potential misclassifications for the stroke diagnosis should also be taken into consideration. However, all the hospitals included in this study are top-ranked public hospitals with 
high quality of electronic diseases diagnosis records in Guangzhou. Another limitation of the present study is the lack of consideration of more age groups, as the distribution of ischemic and hemorrhagic stroke might vary across the age (e.g. 65-74, and $\geq 75$ years), we recommend future studies to examine the association in subgroups as 65-74, and $\geq 75$ years. Due to the limited number of hemorrhagic stroke hospitalizations, studies based on enlarged sample size or in multi-cites should be performed to examine the association in the future. In addition, hypertension, diabetes mellitus and dyslipidemia are important risk factors for stroke [4]. Further studies taking the comorbidity of stroke and hypertension, diabetes mellitus and dyslipidemia into consideration could be helpful to identify effective ways to prevent stroke.

\section{Conclusions}

In summary, we found short-term exposure to ambient $\mathrm{SO}_{2}$ may significantly increase the risks of hospitalization for ischemic stroke. The findings may contribute to a better understanding of the health effects of $\mathrm{SO}_{2}$.

\section{Supplementary information}

Supplementary information accompanies this paper at https://doi.org/10. 1186/s12889-020-8354-0

Additional file 1 Supplementary Table 1. The distribution of ischemic and hemorrhagic stroke events by age. Supplementary Table 2. Correlations between air pollutants and meteorological factors.

Supplementary Table 3. The percent change of stroke risk associated with $10 \mathrm{\mu g} / \mathrm{m}^{3}$ and per $\mathrm{IQR}$ increase of $\mathrm{SO}_{2}$ with different $\mathrm{df}$ (sensitivity analysis).

\section{Abbreviations}

$\mathrm{Cl}$ : Confidence interval; DOW: Day of the week; GAM: Generalized additive model; GBD: Global Burden of Disease; ICD-10: International Classification of Diseases, the 10th version; $\mathrm{O}_{3}$ : Ozone; PM: Particulate matter; $\mathrm{SO}_{2}$ : Sulfur dioxide

\section{Acknowledgements}

Not applicable.

\section{Authors' contributions}

SS and QC designed the study. $X \mathrm{~L}$ analyzed the data and drafted the manuscript. $\mathrm{CY}, \mathrm{QH}, \mathrm{DL}, \mathrm{SM}, \mathrm{JH}, \mathrm{RL}$, and TW contributed to the data collection. All authors critically reviewed and approved the manuscript.

\section{Funding}

Not applicable.

\section{Availability of supporting data}

The air pollution data that support the findings of this study are available on request from the corresponding author, Qing Chen. The stroke data are not publicly available due to the privacy restriction. Competing interests. The authors declare they have no competing interests.

\section{Ethics approval and consent to participate}

The protocol of study and accessing the hospital admission data was approved by the ethics committee of School of Public Health of Southern Medical University, and was performed in accordance with the ethical standards noted in the 1964 Declaration of Helsinki and its later amendments.
Consent for publication

Not applicable.

\section{Competing interests}

The authors declare that they have no competing interests.

\section{Author details}

${ }^{1}$ School of Public Health, Southern Medical University, 1838\#Guangzhou North Avenue, Guangzhou, Guangdong 510515, People's Republic of China. ${ }^{2}$ Guangdong Provincial Institute of Public Health, Guangdong Provincial Center for Disease Control and Prevention, Guangzhou, Guangdong 510515, People's Republic of China. ${ }^{3}$ Department of Neurology, Nanfang Hospital, Southern Medical University, 1838\#Guangzhou North Avenue, Guangzhou, Guangdong 510515, People's Republic of China. ${ }^{4}$ Department of Cardiovascular Surgery \& Center for Basic Medical Research, TEDA International Cardiovascular Hospital, Chinese Academy of Medical Sciences, \& Nankai University, Tianjin 300457, China. ${ }^{5}$ Department of Rheumatology, Nanfang Hospital, Southern Medical University, 1838\#Guangzhou North Avenue, Guangzhou, Guangdong 510515, People's Republic of China. ${ }^{6}$ Department of Medicine, Brigham and Women's Hospital and Harvard Medical School, Boston, MA 02115, USA. DDepartment of Pain Management, The State Key Clinical Specialty for Pain Medicine, The Second Affiliated hospital, Guangzhou Medical University, Guangzhou, Guangdong 510260, People's Republic of China. ${ }^{8}$ Department of Interventional Radiology, Guangzhou First People's Hospital, School of Medicine, South China University of Technology, No.1 Panfu Road, Guangzhou 510180, Guangdong, People's Republic of China. ${ }^{9}$ First Clinical Medicine College, Southern Medical University, 1838\#Guangzhou North Avenue, Guangzhou, Guangdong 510515, People's Republic of China.

Received: 7 August 2019 Accepted: 13 February 2020

Published online: 21 February 2020

\section{References}

1. Collaborators GBDLRoS, Feigin VL, Nguyen G, Cercy K, Johnson CO, Alam T, Parmar PG, Abajobir AA, Abate KH, Abd-Allah F, et al. global, regional, and country-specific lifetime risks of stroke, 1990 and 2016. N Engl J Med. 2018;379(25):2429-37.

2. Collaborators GBDS. Global, regional, and national burden of stroke, 1990 2016: a systematic analysis for the global burden of disease study 2016. Lancet Neurol. 2019;18(5):439-58.

3. Wu S, Wu B, Liu M, Chen Z, Wang W, Anderson CS, Sandercock P, Wang Y, Huang Y, Cui L, et al. Stroke in China: advances and challenges in epidemiology, prevention, and management. Lancet Neurol. 2019;18(4):394-405.

4. Beaney TBL, Castillo RR, Charchar FJ, Cro S, Damasceno A, Kruger R, Nilsson PM, Prabhakaran D, Ramirez AJ, Schlaich MP, Schutte AE, Tomaszewski M, Touyz R, Wang JG, Weber MA, Poulter NR. May Measurement Month 2018: A pragmatic global screening campaign to raise awareness of blood pressure by the International Society of Hypertension. Eur Heart J. 2019(40):2006-17.

5. Chia YCCS, Chew BN, Devaraj NK, Siti Suhaila MY, Tay CL, Kang PS, Verna Lee KM, Kong SZ, Teoh SW, Nurjasmine AJ. May measurement month 2017 blood pressure screening: findings from Malaysia-South-East Asia and Australasia. Eur Heart J Suppl. 2019;21(April):D77-9.

6. Shah AS, Lee KK, McAllister DA, Hunter A, Nair H, Whiteley W, Langrish JP, Newby DE, Mills NL. Short term exposure to air pollution and stroke: systematic review and meta-analysis. BMJ. 2015;350:h1295.

7. Yitshak Sade M, Novack V, Ifergane G, Horev A, Kloog I. Air pollution and ischemic stroke among young adults. Stroke. 2015;46(12):3348-53.

8. Zeng W, Zhang Y, Wang L, Wei Y, Lu R, Xia J, Chai B, Liang X. Ambient fine particulate pollution and daily morbidity of stroke in Chengdu, China. PloS One. 2018;13(11):e0206836.

9. Ge E, Fan M, Qiu H, Hu H, Tian L, Wang X, Xu G, Wei X. Ambient sulfur dioxide levels associated with reduced risk of initial outpatient visits for tuberculosis: a population based time series analysis. Environ Pollut. 2017;228:408-15.

10. Wang L, Liu C, Meng X, Niu Y, Lin ZJ, Liu YN, Liu JM, Qi JL, You JL, Tse LA et al. Associations between short-term exposure to ambient sulfur dioxide and increased cause-specific mortality in 272 Chinese cities. Environ Int 2018;117:33-9. 
11. Liu H, Tian YH, Xu Y, Huang Z, Huang C, Hu YH, Zhang J. Association between ambient air pollution and hospitalization for ischemic and hemorrhagic stroke in China: a multicity case-crossover study. Environ Pollut. 2017;230:234-41.

12. Tian Y, Liu H, Zhao Z, Xiang X, Li M, Juan J, Song J, Cao Y, Wang X, Chen L, et al. Association between ambient air pollution and daily hospital admissions for ischemic stroke: a nationwide time-series analysis. PLoS Med. 2018;15(10):e1002668.

13. Dong H, Yu Y, Yao S, Lu Y, Chen Z, Li G, Yao Y, Yao X, Wang SL, Zhang Z. Acute effects of air pollution on ischaemic stroke onset and deaths: a timeseries study in Changzhou, China. BMJ Open. 2018;8(7):e020425.

14. Maheswaran R, Pearson T, Beevers SD, Campbell MJ, Wolfe CD. Air pollution and subtypes, severity and vulnerability to ischemic stroke-a population based case-crossover study. PLoS One. 2016;11(6):e0158556.

15. Xiang H, Mertz KJ, Arena VC, Brink LL, Xu X, Bi Y, Talbott EO. Estimation of short-term effects of air pollution on stroke hospital admissions in Wuhan, China. Plos One. 2013;8(4):e61168.

16. Guo P, Wang Y, Feng W, Wu J, Fu C, Deng H, Huang J, Wang L, Zheng M, Liu H. Ambient Air Pollution and Risk for Ischemic Stroke: A Short-Term Exposure Assessment in South China. Int J Environ Res Public Health. 2017;14(9).

17. Zhou K, Ye YH, Liu Q, Liu AJ, Peng SL. Evaluation of ambient air quality in Guangzhou, China. J Environ Sci (China). 2007;19(4):432-7.

18. Yang J, Yin P, Zhou M, Ou CQ, Li M, Li J, Liu X, Gao J, Liu Y, Qin R, et al. The burden of stroke mortality attributable to cold and hot ambient temperatures: epidemiological evidence from China. Environ Int. 2016;92-93:232-8.

19. Lin H, Tao J, Du Y, Liu T, Qian Z, Tian L, Di Q, Rutherford S, Guo L, Zeng W, et al. Particle size and chemical constituents of ambient particulate pollution associated with cardiovascular mortality in Guangzhou, China. Environ Pollut. 2016;208(Pt B):758-66.

20. Yu ITS, Zhang Y, San Tam WW, Yan QH, Yj X, Xj X, Wu W, Ma WJ, Tian LW, Tse LA, et al. Effect of ambient air pollution on daily mortality rates in Guangzhou, China. Atmos Environ. 2012;46:528-35.

21. Huang $D, X u J$, Zhang $S$. Valuing the health risks of particulate air pollution in the Pearl River Delta, China. Environ Sci Policy. 2012;15(1):38-47.

22. Liu T, Zhang YH, Xu YJ, Lin HL, Xu XJ, Luo Y, Xiao J, Zeng WL, Zhang WF, Chu $C$. The effects of dust-haze on mortality are modified by seasons and individual characteristics in Guangzhou, China. Environ Pollut. 2014;187:116-23.

23. Li X, Xiao J, Lin H, Liu T, Qian Z, Zeng W, Guo L, Ma W. The construction and validity analysis of $\mathrm{AQHI}$ based on mortality risk: A case study in Guangzhou, China. Environ Pollut. 2017;220(Pt A):487-94.

24. He JR, Liu Y, Xia XY, Ma WJ, Lin HL, Kan HD, Lu JH, Feng Q, Mo WJ, Wang P, et al. Ambient temperature and the risk of preterm birth in Guangzhou, China (2001-2011). Environ Health Perspect. 2016;124(7):1100-6.

25. Guo P, Zheng M, Wang Y, Feng W, Wu J, Deng C, Luo G, Wang L, Pan B, Liu $H$. Effects of ambient temperature on stroke hospital admissions: results from a time-series analysis of 104,432 strokes in Guangzhou, China. Sci Total Environ. 2017;580:307-15.

26. Peng RD, Dominici F, Louis TA. Model choice in time series studies of air pollution and mortality. J Royal Stat Soc. 2006;169(2):179-203.

27. Peng RD, Dominici F, Pastor-Barriuso R, Zeger SL, Samet JM. Seasonal analyses of air pollution and mortality in 100 US cities. Am J Epidemiol. 2005;161 (6):585-94.

28. Wong CM, Vichit-Vadakan N, Kan H, Qian Z. Public health and air pollution in Asia (PAPA): a multicity study of short-term effects of air pollution on mortality. Environ Health Perspect. 2008;116(9):1195-202.

29. Wellenius GA, Schwartz J, Mittleman MA. Air pollution and hospital admissions for ischemic and hemorrhagic stroke among medicare beneficiaries. Stroke. 2005;36(12):2549-53.

30. Chen R, Yin P, Meng X, Wang L, Liu C, Niu Y, Lin Z, Liu Y, Liu J, Qi J, et al. Associations between ambient nitrogen dioxide and daily cause-specific mortality: evidence from 272 Chinese cities. Epidemiol. 2018;29(4):482-9.

31. Routledge HC, Manney S, Harrison RM, Ayres JG, Townend JN. Effect of inhaled Sulphur dioxide and carbon particles on heart rate variability and markers of inflammation and coagulation in human subjects. Heart. 2006;92(2):220-7.

32. Sang N, Yun Y, Li H, Hou L, Han M, Li G. SO2 inhalation contributes to the development and progression of ischemic stroke in the brain. Toxicol Sci. 2010;114(2):226-36.
33. AK-y L. Limits to vehicle emission control: a case of Guangzhou. Procedia Environ Sci. 2016;36:106-13.

\section{Publisher's Note}

Springer Nature remains neutral with regard to jurisdictional claims in published maps and institutional affiliations.

\section{Ready to submit your research? Choose BMC and benefit from:}

- fast, convenient online submission

- thorough peer review by experienced researchers in your field

- rapid publication on acceptance

- support for research data, including large and complex data types

- gold Open Access which fosters wider collaboration and increased citations

- maximum visibility for your research: over $100 \mathrm{M}$ website views per year

At BMC, research is always in progress.

Learn more biomedcentral.com/submissions 